\title{
ECONOMIC EFFECTS OF FAIRS - A COMPLEX APPROACH
}

\author{
László Kárpáti \\ Budapest Business School \\ e-mail: karpati.laszlo@kvifk.bgf.hu
}

\begin{abstract}
A complex economic evaluation of fairs / exhibitions can be considered as a novelty in the current literature. In this novel approach, each stakeholder group involved in a fair is evaluated in numerical terms, taking into account the specific cash inflow and outflow categories of that group. The net cash flow is considered as the economic value since it filters out the accumulations. Adding together all the categories, the so-called complex economic value and effectiveness is established regarding the fair surveyed. A numerical model entitled KAVA was developed in order to carry out the calculations for the complex economic effectiveness of the fair. A practical example of using the model is also shown in the paper.
\end{abstract}

Key words: fair, economics, cash flow, model, effectiveness

\section{Introduction}

fairs and exhibitions can be considered as one of the oldest means of marketing, looking back over several thousand years' past. Many authors have dealt with the evaluation of these events, examining them from several viewpoints; however, fairs / exhibitions have not yet been evaluated from an economic viewpoint in a complex way, taking into account the environment, region or settlement in which they are held. In this article the author presents a model that attempts to answer the questions above in a complex way, providing numeric figures regarding the economic effectiveness of a fair. The acronym of the newly developed model is KAVA. In this paper, the author presents the theoretical background of the KAVA model and one practical example.

\section{Literature review}

an array of publications have dealt with the evaluation of the effects of fairs / exhibitions in marketing literature. The approach taken by the authors of such publications is mainly qualitative, though occasionally quantitative, too. The main characteristics of the existing publications are that they investigate one or more objectives from the view of the stakeholders of fairs, and generally analyse them independently of their environment / region / settlement. The publications cited below, however, include invaluable components for creating a more complex model, since the different approaches used by previous authors can be usefully incorporated into a new model. For the figures on economic effectiveness, Nabradi's (2008) article provided the main guidelines, while in connection with consumer behavior, the method offered by Csapo (2006) was followed. In creating the KAVA model, the publications of the authors listed below have been especially invaluable: Ali-Knight (2008), Arany (2002), Bakos (2004), Biro (1994), Csizmadia (2004), Farago (2005), Fenich (2008), Gauder (2006), Gyarmati (2005), Jarasi (2004), Kozma (1999), Masterman \& Wood (2008), McDonnell (2008), Robinson \& Long (2008), Rogers \& Davidson (2008), Rutherford \& Goldblatt (2008), Shone (2008/a, 2008/b), and Tomecsko (2003). In addition to those publications, two further publications which did not contain the authors' name(s) also proved useful: Anonymous (2004) and Vatel Team (2006).

The main publication inspiring this paper / upon which this paper is based was that of Varga \& Karpati (2006), in which the authors described their evaluation of fairs' stakeholders quantitatively in a complex way. This article served as a basis for creating the complex economic model of fair evaluation, named KAVA after the initials of the authors.

\section{Main approach of the KAVA model}

The main approach of the KAVA model is to separately evaluate stakeholders' roles in a given fair economically, then summarising them to determine the complex economic value of the fair. Based on Varga \& Karpati's (2006) article, mentioned above, the main stakeholder groups involved in a fair can be distinguished, as below:
a) organiser
b) exhibitor
c) professional buyer
d) expert company
e) individual expert
f) future expert / student 
g) ordinary visitor / layperson

h) region / settlement (the laughing third)

The list above contains all the stakeholders who are in some way connected financially to a fair / exhibition, and whose role can therefore be calculated in monetary terms linked with an event. In the KAVA model, each stakeholder has three money flow categories, as below:

- money inflow for the given stakeholder, called 'yield value' in the model

- money outflow for the given stakeholder, called 'cost value' in the model

- net cash flow, calculated as money inflow minus money outflow, called 'economic value' in the model

The task, therefore, is that the yield and cost values have to be measured for each stakeholder separately, and then used to determine the economic value by means of subtraction. In using the model, we have to take into account that there are numerous values which for one stakeholder might mean money inflow, while for another might mean money outflow. Let us take the example of the admission fee: this represents a cash outflow for the visitor, but a cash inflow for the organiser. Due to this characteristic of the model, calculation of the yield and cost values contain accumulations. The method of calculation, namely subtraction of the cost from the yield value to ascertain the economic value, however, filters this accumulation out of the model. In the KAVA model, therefore, the economic value figure shows the real monetary value of the fair for a stakeholder group, which can be either negative or positive, due to the "net characteristics" of this figure. When we summarise the economic values of all the stakeholder groups by their sign and absolute values, the complex economic value of the fair / exhibition is determined.

In the following points, the theoretical method for the determination of economic values in case of each stakeholder group is shown.

\section{Determination of the stakeholders' economic values}

\section{Organiser}

a) Determination of the yield value

The yield value for the organiser can be determined by addition of the factors below:

- income from the inner and outer space sold

- income from equipment rented out

- income from the admission fee

- state and local subsidisation

- collected parking fee

- other cash inflows

b) Determination of the cost value

The cost value for the organiser can be determined by adding together the cost categories listed below:
- cost of the hired space (inner and outer) and the equipment hired

- cost of exhibition construction, such as cost of logistics, cost of hired labour and premium wage for own labour force

- transportation, accommodation and meals for the labour force

- cost of security service

- cost of public utility and other public services

- public relations and promotional costs

- insurance cost

- any other cash outflow connected to the organisational activities

c) Determination of the economic value

As shown above, the economic value for the organiser of the fair / exhibition can be determined as a product of the yield value minus the cost value. This calculation is the same for each stakeholder group, so will not be shown in the paper from now on.

\section{Exhibitor}

a) Determination of the yield value

The yield value for the exhibitors can be determined by addition of the factors below:

- average direct sales at the fair

- expected potential sales surplus supposing N years' lasting positive effect of the fair

- potential savings due to the non-executed partner visits (because they are also on site at the same time)

- potential savings due to the non-executed competitor visits

- potential savings due to the non-executed visits to neighboring concentrated market-place (replacing effect)

b) Determination of the cost value

The cost value for the exhibitor can be determined by adding together the cost categories listed below:

- cost of direct sales at the fair

- surplus cost due to surplus sales as an effect of the fair (see the point above)

- booth and space hiring fee

- cost associated with equipment purchase or hiring

- hired labour cost, premium for own employees

- labour transportation, accommodation and meals cost

- PR and promotional costs

\section{Professional buyer}

a) Determination of the yield value

The yield value for the professional buyers can be determined through the addition of the factors below:

- potential savings due to non-executed partner visits (because they are also on site at the same time)

- value of savings due to special fair discount

- "professional welfare effect" due to the professional content of the fair 
b) Determination of the cost value

The cost value for the professional buyer can be determined by adding together the cost categories listed below:

- travel cost

- cost of accommodation and meals

- admission fee

\section{Expert company}

a) Determination of the yield value

The yield value for the expert company can be determined through the addition of the factors below:

- potential savings due to non-executed partner visits (because they are also on site at the same time)

- "professional welfare effect" due to the professional content of the fair

- expected direct expert income connected to the fair

b) Determination of the cost value

The cost value for the expert company can be determined by adding together the cost categories listed below:

- travel cost

- cost of accommodation and meals

- admission fee

\section{Individual expert}

The methodology as regards individual experts is the same as for the expert company (see above). It is worthwhile creating a new category, however, because individual experts are generally connected to far fewer partners than are expert companies.

\section{Future expert / student}

It is novel to create this category among stakeholders, since no publication has dealt thus far with students of higher education as a separate group. For them, the professional experience acquired at a fair can potentially be utilised during their studies, which may lead to higher grades, a higher scholarship and as a result of that, potentially to a higher salary after graduation.

In the cash outflow side, in addition to the admission fee one can count on travel and subsistence costs in case of visiting students.

\section{Ordinary visitor / layman}

The ordinary visitor / layperson does not raise any professional question in connection with the fair / exhibition, but visits this event basically for its entertainment value. For them the "money inflow side" can be determined as well-spent leisure time or interesting entertainment, a hypothetical value which can be compared to the cost of the admission fee. We can create several categories among the laypeople, from those who greatly enjoy the fair and evaluate its entertainment value equivalent to 10 times the admission fee, down to a category in which the people consider the admission fee as money lost. Market research is necessary in order to determine the category in which the visitors belong. A random sampling method is suggested in this case.

The cost value incorporates the admission fee, as well as travel costs and subsistence.

\section{Region / settlement ("the laughing third")}

The label "the laughing third" refers to the situation in which the settlement / region also makes a profit from the fair / exhibition, despite not working towards the goals of this event. In the following points, the main factors to take into account in this case are summarised.

a) Determination of the yield value

The yield value for the region / settlement can be determined by the addition of the factors below:

- number of non-local visitors and their average spending there

- surplus spending in the hotels including the potential extra "fair rate" in the region

- surplus spending on meals in the region

- surplus tourist tax income

- savings of local promotional cost due to the fair's "piggyback" effect

- potential long-term effect of increased number of tourists and their spending margin in the region

b) Determination of the cost value

The cost value for the region / settlement can be determined by adding together the cost categories listed below:

- cost ratio of the income categories listed above under point (a)

- surplus costs in the region in connection with environmental protection, cleaning and security services

- higher surplus in accidents due to the increased number of visitors and the material loss caused by it

- higher criminal activity in the region and the material loss caused by it

\section{Complex economic evaluation of a fair}

The main yield and cost categories of the KAVA model have been described in the previous section. Due to professional considerations, both the exhibitors and the professional visitors can also be classified into 3 categories - large, medium and other (small) - based on the sizes of the companies in question. In each category, many inputs for the yield and the cost sides have to be determined in order to establish an economic value that does not contain any money accumulation. After determining the economic values of each category, they can be added together and the so-called complex economic value of the fair can be determined in one single figure.

As can be seen above, the KAVA model requires many numerical inputs. The inputs are classified into 14 groups, 
and altogether 242 input figures are needed to run the model. The number of outputs totals 174 . The most important output, however, is the total economic effectiveness of the exhibition including the valuefor the region in which the exhibition is organised.

These can be established through analysing the recent economic environment, but primarily by surveying the different stakeholders of the fair. The model can also be used for planning, too, when the planner uses expected figures for the future and WHAT - IF analysis to develop new scenarios. The "ideal" fair is a theoretical one at which all stakeholders have positive economic values. If one or more groups' economic values were negative or very negative, their long-term participation in the fair would be questionable.

Technically, the KAVA model is developed using the Excel programme, meaning that practically anybody can use this model for analysis or planning purposes.

\section{Practical example}

The KAVA model was tested on several exhibitions held / organised (?) by Varga in Hungary and Poland. The results of one Hungarian exhibition are shown below.

The main character of the OMÉK 2005 exhibition was agribusiness and food. It was held in Budapest (Hungary) in August 2005, and is considered the main agribusiness fair in the country. The total number of exhibitors is 600 , of whom 25 were large companies (annual turnover: 50 Million USD +), 60 were medium-sized companies (annual turnover between 5 and 50 Million USD) and the rest were smaller exhibitors. The total number of visitors was 110,000 , of whom 70,000 were considered non-professional visitors. The number of local visitors was 90,000 . Out of the 40,000 professional visitors, 500 were considered large companies, 3500 medium-sized companies, and the rest were from other companies or individuals, including 2650 expert companies and future experts.

The main outputs of the model can be seen in Table 1 .

As can be seen in Table 1, the total net economic value expressed in USD of OMÉK 2005 fair is close to 10 Million, calculated from the local currency of Hungarian Forint (1 911 576 thousand HUF) by the exchange rate of $200 \mathrm{HUF} / \mathrm{USD}$, characteristic at the time of calculation.

The first column shows the calculated net economic value for each of the stakeholders involved in the fair by the KAVA model algorithm.

The second column shows the allocation of those values in percentage. Please note that due to the net value calculation, some figures are negative as the cost value for participation is higher than the possible benefits. In this case, small scale exhibitors seem to produce such values, making the summarised exhibitor value also slightly negative. At the same time, however, for the large exhibitors the economic value is quite positive. The same tendency can be seen in case of the professional buyers, too, where the large companies are the real beneficiaries of the fair. The real winner is the organiser, which gains nearly half of the net economic value. The other winner is the capital city Budapest itself, representing over 40 per cent of the total net economic vale, due to the increased demand for accommodation and entertainment. These two stakeholders represent about 90 per cent of the total economic value of the fair. This extremely high percentage was suspected so far, but never shown so clearly in a publication.

Table 1: Economic effectiveness figures of the OMÉK 2005 fair

\begin{tabular}{|c|c|c|c|}
\hline Category & $\begin{array}{l}\text { Economic } \\
\text { Value in } \\
\text { thousand } \\
\text { USD }\end{array}$ & $\begin{array}{c}\text { Economic } \\
\text { Value } \\
\text { allocation, } \\
\text { per cent }\end{array}$ & $\begin{array}{c}\text { Economic } \\
\text { Effec- } \\
\text { tiveness, } \\
\text { per cent }\end{array}$ \\
\hline Organiser & 4680.6 & 48.97 & 461.14 \\
\hline Exhibitor: large & 396.5 & 4.15 & 2.98 \\
\hline Exhibitor: medium-sized & 4.1 & 0.04 & 0.09 \\
\hline Exhibitor: small / other & -439.6 & -4.60 & -12.56 \\
\hline Exhibitors together & -39.0 & -0.41 & -0.18 \\
\hline Professional buyer: large & 622.5 & 6.51 & 149.10 \\
\hline Professional buyer: medium-sized & 63.0 & 0.66 & 3.24 \\
\hline Professional buyer: small/other & 108.0 & 1.13 & 1.40 \\
\hline Professional buyers together & 793.5 & 8.30 & 7.86 \\
\hline Expert company & 90.4 & 0.95 & 42.01 \\
\hline Individual expert & 6.6 & 0.07 & 3.89 \\
\hline Future expert/student & 14.9 & 0.16 & 19.60 \\
\hline Expert visitors together & 866.4 & 9.07 & 2.73 \\
\hline $\begin{array}{l}\text { Expert visitors and exhibitors } \\
\text { together }\end{array}$ & 5547.0 & 58.04 & 16.95 \\
\hline Ordinary visitor/layperson & 19.0 & 0.20 & 1.09 \\
\hline Experts and visitors together & 5566.0 & 58.24 & 16.15 \\
\hline $\begin{array}{l}\text { Region/settlement ("the laughing } \\
\text { third") }\end{array}$ & 3991.9 & 41.76 & 246.01 \\
\hline Fair total & 9557.9 & 100 & 26.48 \\
\hline
\end{tabular}

The third column shows the figure of economic effectiveness for a given stakeholder, calculated as an economic value divided by the cost value and expressed in percentage. Any figure over 20-30 per cent can be considered as a desirable value, even taking into account the risk premiums as well. In addition to the organiser and the city, the large-scale professional buyers show a high value of over 100 per cent. The expert company and future expert categories show acceptable results, but for other stakeholders, the exhibition is not very economically efficient. Surprisingly, this is true for the large exhibitors, as well, where the economic value itself was quite high anyway. This can be explained by the high cost of participation, which pushes down the effectiveness figure to 3 per cent. The small exhibitors seem to be the real losers of the fair, a phenomenon observed no only in this case, but in every fair we examined by Varga, as well.

As shown, the KAVA model visualises the economic values quite spectacularly (sounds strange for an academic publication. 'Very clearly'?)and incorporates data from all the stakeholders involved. In this sense, the model can be considered unique in the literature so far. Of course, the usefulness 
of the model is a function of the reliability of the input data, meaning that they must be established through intensive and careful market research as well as auditing as regards the fair and its environment.

\section{References}

Ali-Knight et al. (2008): „Case Studies in Festival and Event Marketing and Cultural Tourism" ISBN: 1905369034, Blackwell Online

Anonymous (2004): „Eseménymarketing” (,Event Marketing”) Rendezvénymagazin, No. 4, Budapest

Arany et al. (2002): „Üzleti rendezvényszervezés” („Business Event Management") B+V Publishing House, Budapest

Bakos (2004). „Rendezvényszervezési útmutató” („Event Management Guide") College of Szolnok

Bíró et al. (1994): „Kiállítók kézikönyve” („Exhibitors’ Handbook”) Budapest

Csapó et al. (2006): Efficient Consumer Response (MBA lecture note), AGRIMBA Publishing, Warsaw

Csizmadia (2004): „Rendezvényszervezés” („Event Organization”) KVIFK Budapest

Faragó (2005): „A hivatásturizmus trendjei” (,Trends of Professional Tourism") Turizmus Bulletin, Budapest

Fenich (2008): „Meetings, Expositions, Events and Conventions” ISBN: 0132340577, Blackwell Online

Gauder (2006): „A vásárok szerepe a városfejlesztésben” („Role of Fairs in Settlement Development") Marketing és Menedzsment, No. 2-3. Pécs

Gyarmati (2005): „Rendezvényszervezési kalauz” („Event Organization Guide") Athenaeum 2000 Publishing House, Budapest

Járási (2004): „Rendezvényszervezés” (,Event Organization”) JGYF Publishing House, Szeged
Kozma (1999): „Kiállítások és vásárok Északkelet-Magyarország három nagyvárosában” („Fairs and Exhibitions in 3 Cities of NorthEast Hungary") Földrajzi Értesítő Vol. XLVIII. No. 3-4. Budapest

Masterman - Wood (2008): ,Innovative Marketing Communication Strategies for the Events Industry" ISBN: 0750663618, Blackwell Online

Nabradi (2008): Különböző szintű hatékonysági mutatók (different effectiveness figures) in Hatékonyság a mezőgazdaságban (Effectiveness in Agriculture) ISBN: 978-963-502-889-4, Agroinform Publishing House, Budapest

McDonnell et al. (2008): , Festival and Special Event Management” ISBN: 0471421820, Blackwell Online

Robinson - Long (2008): „Festival and Tourism Marketing, Management and Evaluation" ISBN: 1901888347, Blackwell Online

Rogers - Davidson (2008): „Marketing Destination and Venues for Conferences, Conventions and Business Convention and Event Perspective" ISBN: 0750667001, Blackwell Online

Rutherford Silvers - Jeff Goldblatt (2008): „Professional Event Coordination" ISBN: 0471263052, Blackwell Online

Shone et al. (2008): „Successful Event Management” ISBN: 1894800768, Blackwell Online

Shone (2008): „The Business of Conferences a Hospitality Sector Overview for the UK and Ireland" ISBN: 0750640995, Blackwell Online

Tomecskó (2003): „Konferencia típusú rendezvények szervezése” („Organization of Conference-Type Events”) BGF Publishing, Budapest

Varga - Karpati (2006). "A kiállítások hatásának értékelése" ? ("Evaluations of effect of exhibitions"). AVA3 Conference Proceedings, Debrecen

Varga (2008): „A mezőgazdasági kiállítások vonzáskörzetének meghatározása.” („Determination of Attractiveness of Agricultural Fairs") Proceedings of the $50^{\text {th }}$ Georgikon Days, Keszthely

Vatel team (2006): „A helyszín szerepe és súlya a rendezvény lebonyolításában” (,Role and Weight of the Venue in Organization of an Event") E-Book: www.vatel.hu, Budapest 
